\title{
SISTEM PENDUKUNG KEPUTUSAN PEMILIHAN TOKO HANDPHONE TERBAIK DI KOTA PADANGSIDIMPUAN MENGGUNAKAN METODE ORESTE
}

\author{
Alwendi'), Dasril Aldo ${ }^{2)}$ \\ Ilmu Komputer dan Informatika, Universitas Graha Nusantara, Padangsidimpuan \\ Sistem Informasi, STMIK GICI, Batam \\ email: alwendi60@gmail.com ${ }^{1)}$, dasrilaldo1994@gmail.com ${ }^{2)}$
}

\begin{abstract}
Abstrak
Penelitian ini akan membahas tentang pemilihan toko handphone terbaik di kota Padangsidimpuan. Penelitian ini dilakukan untuk mengetahui toko handphone terbaik di kota Padangsidimpuan menurut konsumen yang diberikan kepada konsumen melalui Kuesioner. Penelitian ini menggunakan Sistem Pendukung Keputusan dengan metode Oreste. Metode Oreste merupakan salah satu metode Sistem Pendukung Keputusan yang mengadopsi Besson Rank, yakni pendekatan skala prioritas dari setiap indicator kriteria. Data yang digunakan sebagai altenatif adalah data toko handphone di Padangsidimpuan dengan sampel 5 toko dengan 5 kriteria penilaian, yaitu Harga, Kualitas pada Handphone, Pelayanan, Daya Tarik Konsumen dan Lokasi Toko. Tahap-tahap yang dilakukan dalam memilih toko handphone dimulai dengan menganalisa sistem yang sedang berjalan pada toko handphone, kemudian dari hasil analisa dilakukan pembobotan kriteria pada toko handphone, lalu dilakukan pembobotan alternatif pada toko handphone. Setelah itu dilakukan proses hasil peringkat bobot alternatif toko handphone. Berdasarkan data alternatif dan kriteria dengan menggunakan metode Oreste, dapat diambil kesimpulan bahwa toko handphone yang terbaik adalah Toko Selamat Cellular dengan Nilai Preferensi dari Nilai Distance Score sebesar 5,3556. Lebih kecil dibandingkan 4 toko yang lain.
\end{abstract}

\section{Kata Kunci : SPK, Oreste, PemilihanToko Handphone, Padangsidimpuan}

\begin{abstract}
This research will discuss about the selection of the best mobile shops in the city of Padangsidimpuan. This research was conducted to find out the best mobile shop in the city of Padangsidimpuangiven to consumers through a Questionnaire. This study uses a Decision Support System with the Oreste method. The Oreste Method is one of the Decision Support System methods supported by Besson Ranking, which is the priority scale of each criterion indicator. The data used as an alternative is the data of cellphone shops in Padangsidimpuanwith a sample of 5 stores with 5 criteria, namely Price, Quality on Cellphones, Services, Consumer Attraction and Store Locations. The mount phase that is carried out in selecting a cell phone shop starts with analyzing the system that is done at the cellphone shop, then from the results of the analysis carried out weighting criteria at the cellphone shop, then carried out alternative weighting at the cell phone shop. After that the process of ranking the weight of alternative handphone shops is carried out. Based on alternative data and criteria using the Oreste method, it can be concluded that the best mobile shop is the Happy Cellular Shop with a Preference Value of Distance Score Value of 5.3556. Smaller than the other 4 stores.
\end{abstract}

Keywords :SPK, Oreste, Selection of Mobile Store, Padangsidimpuan 


\section{PENDAHULUAN}

Sekarang ini banyak sekali toko handphone di Padangsidimpuan yang memperjual belikan handphone baik dalam kondisi baru maupun bekas, keduanya memiliki model, kualitas dan harga yang bervarisi. Ditambah sekarang perkembangan akan handphone terjadi begitu pesat, sehingga mereka akan menawarkan beberapa kemudahan dan peningkatan pelayanan, baik dalam peningkatan toko handphone maupun kualitas handphone itu sendiri.

Pada zaman yang serba elektronik ini pengguna gadget terutama handphone semakin menjamur. Hal itu tentunya menjadi peluang besar bagi para penjual handphone untuk mengais keuntungan. Oleh karena tingginya permintaan konsumen akan handphone tersebut, kini sudah banyak toko- toko yang menjual perangkat-perangkat tersebut, mulai dari handphone dengan fitur yang sederhana sampai yang canggih sekalipun. Hal ini tentunya menjadi tugas tersendiri bagi para penjual handphone untuk melayani pembeli secara baik dan efektif. Banyaknya toko handphone yang menjual berbagai macam produk handphone, membuat pihak toko harus meningkatkan kualitas pelayanan agar para konsumen tertarik membeli produk handphone di toko tersebut.

Persaingan toko handphone di kota Padangsidimpuan membuat peneliti tertarik untuk mengambil topik penelitian yang berkaitan dengan penentuan toko handphone terbaik yang dilihat dari kacamata konsumen (pembeli) [1]. Adapun penentuan toko handphone terbaik ini nantinya akan menggunakan Sistem Pendukung keputusan dengan metode Oreste. Seperti diketahui bahawa Sistem Pendukung Keputusan dapat dimanfaatkan untuk membantu manusia mengambil keputusan dengan cepat, tepat dan konsisten [2]-[5]. Banyak cabang ilmu komputer yang dapat menyelesaikan permasalahan yang bersifat kompleks. Hal ini terbukti dari penelitian terdahulu oleh para peneliti dalam menyelesaikan permasalahan dalam bidang data mining [6]-[9], dalam bidang Fuzzy [10], dalam bidang jaringan saraf tiruan [11]-[14], maupun dalam bidang Sistem Pendukung Keputusan [3]-[4].

\section{Sistem Pendukung Keputusan}

Sistem Pendukung Keputusan merupakan suatu sistem interaktif yang mendukung keputusan dalam proses pengambilan keputusan melalui alternatif - alternatif yang diperoleh dari hasil pengolahan data.

Sistem Pendukung Keputusan adalah sistem yang berbasis komputer yang dapat membantu pengambilan keputusan untuk memecahkan masalah tertentu dengan memanfaatkan data dan model tertentu. Pada dasarnya SPK merupakan pengembangan lebih lanjut dari Sistem Informasi Manajemen terkomputerisasi yang dirancang sedemikian rupa sehingga bersifat interaktif dengan pemakainya. Interaktif dengan tujuan untuk memudahkan integrasi antara berbagai komponen dalam proses pengambilan keputusan seperti prosedur, kebijakan, analisis, pengalaman dan wawasan manajer untuk mengambil keputusan yang lebih baik [11].

Langkah-langkah Pemodelan Sistem Pendukung Keputusan adalah sebagai berikut.

1. Studi Kelayakan (Intelligence) Pada langkah ini, sasaran ditentukan dan dilakukan pencarian prosedur, pengumpulan data, identifikasi 
masalah, identifikasi kepemilikan masalah, klasifikasi masalah, hingga akhirnya terbentuk sebuah pernyataan masalah.

2. Perancangan (Design)

Pada tahapan ini akan diformulasikan model yang akan digunakan dan kriteria- kriteria yang ditentukan. Setelah itu, dicari alternatif model yng bisa menyelesaikan permasalahan tersebut.

3. Pemilihan (Choice)

Setelah pada tahap design ditentukan berbagai alternatif model beserta variabel- variabelnya, pada tahapan ini akan dilakukan pemilihan modelnya, termasuk solusi dari model tersebut. Selanjutnya, dilakukan analisis sensitivitas, yakni dengan mengganti beberapa variabel.

4. Membuat SPK (Decision Support Systems)

Setelah menentukan modelnya berikut adalah mengimplementasikannya.

\section{Metode Oreste}

Oreste menurut Pastijn dan Leysen merupakan metode yang dibangun sesuai untuk kondisi dimana sekumpulan alternatif akan di urutkan berdasarkan kriteria sesuai dengan tingkat kepentingannya. Salah satu proses dalam metode Oreste adalah Besson-rank, adapun Besson-rank tersebut adalah proses pemberian ranking untuk sejumlah kriteria atau alternatif berdasarkan tingkat kepentingannya.

Urutan langkah dalam menentukan peringkat menggunakan metode Oreste (Pastijn \& Leysen, 2009):

a. Pastikan semua penilaian alternative untuk semua kriteria dalam bentuk ordinal. Urutan pertama dalam metode Oreste yaitu Besson-Rank. Ubah data alternatif tiap kriteria ke Besson-rank
Ubah data alternatif tiap kriteria ke Besson-rank

b. Menghitung Distance-score dengan cara menghitung setiap pasangan alternatif-kriteria sebagai nilai "jarak" untuk posisi yang ideal dan ditempati oleh alternatif terbaik untuk kriteria yang paling penting.

c. Menentukan matrik $\mathrm{R} /$ relasi matrik dari skor jarak diatas.

d. Kemudian semua "jarak" nilai diubah menjadi Besson-rank untuk menjaga metode sepenuhnya ordinal. Menentukan Global Besson-rank / rangking global dengan cara mengurutkan nilai tiap alternatif dari nilai terbesar ke nilai terkecil.

\section{METODE PENELITIAN}

Metode adalah tahapan dalam melakukan penelitian untuk mendapatkan data seakurat mungkin, adapun alur penelitian adalah sebagai gambar berikut

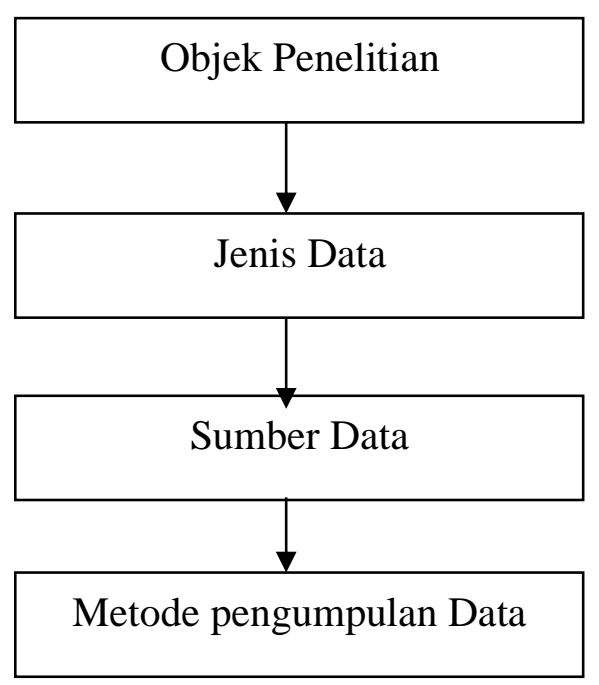

Gambar 3.1 Alur Penelitian

Gambar diatas adalah desain penelitian yang digunakan dalam pemilihan toko handpone yang terbaik .

1. Objek penelitian

$\underline{\text { https://ejournal.stmikgici.ac.id/ }}$ STMIK GICI 
objek penelitian dalam penelitian ini adalah toko handpone di kota padangsidimpuan

2. jenis data data yang digunakan dalam penelitian ini adalah data kuantitatif yaitu data yang digunakan dalam bentuk angka

3. sumber data dalam usaha untuk mendapatkan datadata yang benar sehingga tercapai maksud dan tujuan dalam penelitian ini yaitu data sekunder dan data primer

4. metode pengumpulan data dalam penelitian ini perlu adanya suatu metode tertentu yang akan digunakan dalam pengumpulan data terdiri dari wawancara, observasi , dan studi pustaka.

\section{HASIL DAN PEMBAHASAN}

Adapun algoritma penyelesaian Metode Oreste yaitu sebagai berikut:

1. Langkah 1 : Mendefinisikan terlebih dahulu kriteria-kriteria yang akan di jadikan sebagai tolak ukur penyelesaian masalah

2. Langkah 2 : Mengubah setiap data alternatif ke dalam Besson Rank

3. Langkah 3 : Menghitung Nilai Distance Score setiap pasangan alternatif

4. Langkah 4 : Menghitung Nilai Preferensi $(\mathrm{Vi})=$ Distance Score $* \mathrm{Wj}$

5. Langkah 5 : Melakukan perangkingan

Pada Tabel 1 dapat dilihat kriteria kriteria apa saja yang digunakan dalam pemilihan toko handphone terbaik.

Tabel 1 Kriteria Pemilihan Toko Handphone Terbaik

\begin{tabular}{|c|l|}
\hline No & \multicolumn{1}{|c|}{ Kriteria } \\
\hline 1 & Harga \\
\hline 2 & Kualitas pada Handphone \\
\hline 3 & Pelayanan \\
\hline 4 & Daya Tarik Konsumen \\
\hline 5 & Lokasi \\
\hline
\end{tabular}

Tabel 2 merupakan pemberian nilai bobot kriteria, dimana kriteria kualitas pada handphone dan daya tarik konsumen memiliki nilai tertinggi yang sama, dibandingkan dengan 3 kriteria yang lain, yakni sebesar $30 \%$ atau 0,3. Kriteria selanjutnya adalah Harga dengan bobot $20 \%$ dan nilai 0,2 sedangkan kriteria Pelayanan dan Lokasi memiliki bobot yang sama yakni $10 \%$ dengan nilai 0,1 . Total bobot sebesar $100 \%$ dengan total nilai 1 .

Tabel 2 Nilai Bobot Kriteria $\left(\mathbf{W}_{\mathbf{j}}\right)$

\begin{tabular}{|c|l|c|c|}
\hline No & Kriteria & Bobot(\%) & Nilai \\
\hline 1 & Harga & 20 & 0,2 \\
\hline 2 & $\begin{array}{l}\text { Kualitas pada } \\
\text { Handphone }\end{array}$ & 30 & 0,3 \\
\hline 3 & Pelayanan & 10 & 0,1 \\
\hline 4 & $\begin{array}{l}\text { Daya Tarik } \\
\text { Konsumen }\end{array}$ & 30 & 0,3 \\
\hline 5 & Lokasi & 10 & 0,1 \\
\hline
\end{tabular}

Tabel 3 menunjukkan alternatif toko handphone terbaik yang akan dipilih menggunakan Sistem Pendukung Keputusan dengan metode Oreste.

Tabel 3 Alternatif Toko Handphone

\begin{tabular}{|c|l|}
\hline No & \multicolumn{1}{|c|}{ Alternatif } \\
\hline 1 & Toko Selamat Cellular (A) \\
\hline 2 & Toko Best Cellular (B) \\
\hline 3 & Toko Gerai Samsung (C) \\
\hline 4 & Toko Ramayana Cellular (D) \\
\hline 5 & Toko Benua Cellular (E) \\
\hline
\end{tabular}

Tabel 4 merupakan penilaian terhadap alternatif. Hasil penilaian diberikan oleh responden melalui kuesioner, berikut ini adalah tabel nilai alternatif setiap toko handphone.

Tabel 4 Penilaian dari Setiap Alternatif

\begin{tabular}{|l|c|c|c|c|c|}
\hline \multirow{2}{*}{\multicolumn{1}{|c|}{ Alternatif }} & \multicolumn{5}{|c|}{ Bobot Alternatif } \\
\cline { 2 - 6 } & C1 & C2 & C3 & C4 & C5 \\
\hline $\begin{array}{l}\text { Toko Selamat } \\
\text { Cellular (A) }\end{array}$ & 4 & 5 & 4 & 4 & 5 \\
\hline Toko Best Cellular & 4 & 4 & 3 & 3 & 4 \\
\hline
\end{tabular}

https://ejournal.stmikgici.ac.id/

STMIK GICI 


\begin{tabular}{|l|c|c|c|c|c|}
\hline (B) & & & & & \\
\hline $\begin{array}{l}\text { Toko Gerai } \\
\text { Samsung (C) }\end{array}$ & 4 & 3 & 5 & 4 & 1 \\
\hline $\begin{array}{l}\text { Toko Ramayana } \\
\text { Cellular (D) }\end{array}$ & 3 & 3 & 2 & 2 & 3 \\
\hline $\begin{array}{l}\text { Toko Benua } \\
\text { Cellular (E) }\end{array}$ & 3 & 3 & 2 & 2 & 3 \\
\hline
\end{tabular}

Tabel 5 menunjukkan Nilai Bobot Kriteria Metode Oreste (Kriteria 1).

Tabel 5 Nilai Bobot Kriteria

\begin{tabular}{|c|c|c|l|}
\hline $\begin{array}{c}\text { N } \\
\text { o }\end{array}$ & $\begin{array}{c}\text { Nama } \\
\text { alternatif }\end{array}$ & $\begin{array}{c}\text { Nilai } \\
\text { Alternatif }\end{array}$ & Keterangan \\
\hline 1 & A & 4 & Ranking $=2$ \\
\hline 2 & B & 4 & Ranking $=2$ \\
\hline 3 & C & 4 & Ranking $=2$ \\
\hline 4 & D & 3 & Ranking $=4,5$ \\
\hline 5 & E & 3 & Ranking $=4,5$ \\
\hline
\end{tabular}

Keterangan :

Karena nilai alternatif A, B dan C sama, maka dalam perankingan nya yaitu Ranking 1, 2dan 3. Mean $=(1+2+3) / 3$ $=2$. Begitu pula nilai alternatif $\mathrm{D}$ dan $\mathrm{E}$, Maka dalam perankingan nya yaitu Ranking 4 dan 5.Mean $=(4+5) / 2=4,5$

Tabel 6 Menunjukkan Nilai Bobot Kriteria Metode Oreste (Kriteria 2).

\begin{tabular}{|c|c|c|c|}
\hline No & $\begin{array}{c}\text { Nama } \\
\text { alternatif }\end{array}$ & $\begin{array}{c}\text { Nilai } \\
\text { Alternatif }\end{array}$ & Keterangan \\
\hline 1 & A & 5 & Ranking $=1$ \\
\hline 2 & B & 4 & Ranking $=2$ \\
\hline 3 & C & 3 & Ranking $=4$ \\
\hline 4 & D & 3 & Ranking $=4$ \\
\hline 5 & E & 3 & Ranking $=4$ \\
\hline
\end{tabular}

Keterangan :

Karena nilai alternatif C,D dan E sama, maka perankingan nya yaitu Ranking 3, 4 dan 5. Mean $(3+4+5) / 3=4$.
Tabel 7 menunjukkan Nilai Bobot Kriteria (Kriteria 3).

\begin{tabular}{|c|c|c|c|}
\hline No & $\begin{array}{c}\text { Nama } \\
\text { alternatif }\end{array}$ & $\begin{array}{c}\text { Nilai } \\
\text { Alternatif }\end{array}$ & Keterangan \\
\hline 1 & A & 4 & Ranking $=2$ \\
\hline 2 & B & 3 & Ranking $=3$ \\
\hline 3 & C & 5 & Ranking $=1$ \\
\hline 4 & D & 2 & Ranking $=4,5$ \\
\hline 5 & E & 2 & Ranking $=4,5$ \\
\hline
\end{tabular}

Keterangan :

Karena nilai alternatif D dan E sama, maka perankingan nya yaitu Ranking 4 dan 5. Mean $=(4+5) / 2=4,5$

Tabel 8 Nilai Bobot Kriteria Metode Oreste (Kriteria 4).

\begin{tabular}{|c|c|c|c|}
\hline No & $\begin{array}{c}\text { Nama } \\
\text { alternatif }\end{array}$ & $\begin{array}{c}\text { Nilai } \\
\text { Alternatif }\end{array}$ & Keterangan \\
\hline 1 & A & 4 & Ranking $=1,5$ \\
\hline 2 & B & 3 & Ranking $=3$ \\
\hline 3 & C & 4 & Ranking $=1,5$ \\
\hline 4 & D & 2 & Ranking $=4,5$ \\
\hline 5 & E & 2 & Ranking $=4,5$ \\
\hline
\end{tabular}

Keterangan :

Karena nilai alternatif $\mathrm{A}$ dan $\mathrm{C}$ sama, maka perankingan nya yaitu ranking 1 dan 2. Mean $(1+2) / 2=1,5$ serta D dan E ranking 4 dan 5.Mean $(4+5) / 2=4,5$.

Tabel 9 Nilai Bobot Kriteria Metode Oreste (Kriteria 5).

\begin{tabular}{|c|c|c|c|}
\hline $\begin{array}{c}\text { N } \\
\text { o }\end{array}$ & $\begin{array}{c}\text { Nama } \\
\text { Alternatif }\end{array}$ & $\begin{array}{c}\text { Nilai } \\
\text { Alternatif }\end{array}$ & Keterangan \\
\hline 1 & A & 5 & Ranking $=1$ \\
\hline 2 & B & 4 & Ranking $=2$ \\
\hline 3 & C & 1 & Ranking $=5$ \\
\hline 4 & D & 3 & Ranking $=3,5$ \\
\hline 5 & E & 3 & Ranking $=3,5$ \\
\hline
\end{tabular}

Keterangan :

Karena nilai alternatif D dan E sama, maka perankingan nya yaitu Ranking 3 dan 4. Mean $(3+4) / 2=3,5$. 


Tabel 10 Nilai Normalisasi Bobot Kriteria
Metode Oreste
\begin{tabular}{|c|c|c|c|c|c|c|}
\hline No & $\begin{array}{c}\text { Nama } \\
\text { Alternatif }\end{array}$ & C1 & C2 & C3 & C4 & C5 \\
\hline 1 & A & 2 & 1 & 2 & 1,5 & 1 \\
\hline 2 & B & 2 & 2 & 3 & 3 & 2 \\
\hline 3 & C & 2 & 4 & 1 & 1,5 & 5 \\
\hline 4 & D & 4,5 & 4 & 4,5 & 4,5 & 3,5 \\
\hline 5 & E & 4,5 & 4 & 4,5 & 4,5 & 3,5 \\
\hline
\end{tabular}

Untuk Menghitung Nilai Distance Score Nilai Distanc Score dihitung menggunakan Persamaan(1).

$$
\mathrm{D}\left(\mathrm{a}_{\mathrm{z}}, \mathrm{c}_{\mathrm{j}}\right)=\left[1 / 2 * \mathrm{rc}_{\mathrm{j}}+1 / 2 * \mathrm{r} \mathrm{c}_{\mathrm{j}}(\mathrm{a})^{\mathrm{R}}\right]^{1 / \mathrm{r}}
$$

Setiap pasangan alternatif dan kriteria sebagai skor jarak dan untuk posisi ideal ditempati oleh alternatif terbaik serta kriteria yang paling penting. Skor ini merupakan nilai rata-rata Besson Rank $\mathrm{R}$ $\mathrm{Cj}$ kriteria $\mathrm{Cj}$ dan Besson Rank $\mathrm{R} \mathrm{Cj}$ (a) alternatif a dalam kriteria $\mathrm{Cj}$. Diketahui $\mathrm{R}$ $=5$ dan $\mathrm{Cj}(\mathrm{a})$.

Maka :

$C_{1}$ :

$$
\begin{aligned}
\mathrm{D}(\mathrm{A}, \mathrm{C} 1) & =([1 / 2 * 25]+[1 / 2 * 15]) 1 / 3 \\
& =2,546 \\
\mathrm{D}(\mathrm{B}, \mathrm{C} 1) & =([1 / 2 * 25]+[1 / 2 * 15]) 1 / 3 \\
& =2,546
\end{aligned}
$$

$\mathrm{D}(\mathrm{C}, \mathrm{C} 1)=([1 / 2 * 25]+[1 / 2 * 15]) 1 / 3$

$$
=2,546
$$

$\mathrm{D}(\mathrm{D}, \mathrm{C} 1)=([1 / 2 * 4,55]+[1 / 2 * 15]) 1 / 3$

$$
=9,737
$$

$\mathrm{D}(\mathrm{E}, \mathrm{C} 1)=([1 / 2 * 4,55]+[1 / 2 * 15]) 1 / 3$

$$
=9,737
$$

$\mathrm{C}_{2}$ :

$$
\begin{aligned}
\mathrm{D}(\mathrm{A}, \mathrm{C} 2) & =([1 / 2 * 15]+[1 / 2 * 25] 1 / 3 \\
& =2,546 \\
\mathrm{D}(\mathrm{B}, \mathrm{C} 2) & =([1 / 2 * 25]+[1 / 2 * 25]) 1 / 3 \\
& =3,175 \\
\mathrm{D}(\mathrm{C}, \mathrm{C} 2) & =([1 / 2 * 45]+[1 / 2 * 25]) 1 / 3 \\
& =8,082
\end{aligned}
$$

$$
\begin{aligned}
\mathrm{D}(\mathrm{D}, \mathrm{C} 2) & =([1 / 2 * 45]+[1 / 2 * 25]) 1 / 3 \\
& =8,082 \\
\mathrm{D}(\mathrm{E}, \mathrm{C} 2) & =([1 / 2 * 45]+[1 / 2 * 25]) 1 / 3 \\
& =8,082
\end{aligned}
$$

$\mathrm{C}_{3}$ :

$\mathrm{D}(\mathrm{A}, \mathrm{C} 3)=([1 / 2 * 25]+[1 / 2 * 35]) 1 / 3$

$$
=5,161
$$

$\mathrm{D}(\mathrm{B}, \mathrm{C} 3)=([1 / 2 * 35]+[1 / 2 * 35]) 1 / 3$

$$
=6,240
$$

$\mathrm{D}(\mathrm{C}, \mathrm{C} 3)=([1 / 2 * 15]+[1 / 2 * 35]) 1 / 3$

$$
=4,960
$$

$\mathrm{D}(\mathrm{D}, \mathrm{C} 3)=([1 / 2 * 4,55]+[1 / 2 * 35]) 1 / 3$

$=10,145$

$\mathrm{D}(\mathrm{E}, \mathrm{C} 3)=([1 / 2 * 4,55]+[1 / 2 * 35]) 1 / 3$

$$
=10,145
$$

$\mathrm{C}_{4}$ :

$\mathrm{D}(\mathrm{A}, \mathrm{C} 4)=([1 / 2 * 1,55]+[1 / 2 * 45]) 1 / 3$ $=8,020$

$\mathrm{D}(\mathrm{B}, \mathrm{C} 4)=([1 / 2 * 35]+[1 / 2 * 45]) 1 / 3$ $=8,589$

$\mathrm{D}(\mathrm{C}, \mathrm{C} 4)=([1 / 2 * 1,55]+[1 / 2 * 45]) 1 / 3$

$$
=8,020
$$

$\mathrm{D}(\mathrm{D}, \mathrm{C} 4)=([1 / 2 * 4.55]+[1 / 2 * 45]) 1 / 3$

$$
=11,278
$$

$\mathrm{D}(\mathrm{E}, \mathrm{C} 4)=([1 / 2 * 4,55]+[1 / 2 * 45]) 1 / 3$

$$
=11,278
$$

C5:

$\mathrm{D}(\mathrm{A}, \mathrm{C} 5)=([1 / 2 * 15]+[1 / 2 * 55]) 1 / 3$

$$
=11,605
$$

$\mathrm{D}(\mathrm{B}, \mathrm{C} 5)=([1 / 2 * 25]+[1 / 2 * 55]) 1 / 3$

$$
=11,643
$$

$\mathrm{D}(\mathrm{C}, \mathrm{C} 5)=([1 / 2 * 55]+[1 / 2 * 55]) 1 / 3$

$$
=14,620
$$

$\mathrm{D}(\mathrm{D}, \mathrm{C} 5)=([1 / 2 * 3,55]+[1 / 2 * 55]) 1 / 3$

$$
=12,220
$$

$\mathrm{D}(\mathrm{E}, \mathrm{C} 5)=([1 / 2 * 3,55]+[1 / 2 * 55]) 1 / 3$

$$
=12,220
$$


Hasil Akumulasi Nilai Distance Score

Tabel 11 Menunjukkan Nilai Akumulasi Distance Score.

\begin{tabular}{|c|c|c|c|c|c|c|}
\hline $\begin{array}{c}\mathbf{N} \\
\mathbf{0}\end{array}$ & $\begin{array}{c}\text { Nama } \\
\text { Alternati } \\
\text { f }\end{array}$ & C1 & C2 & C3 & C4 & C5 \\
\hline 1 & A & $\begin{array}{c}2,54 \\
6\end{array}$ & $\begin{array}{c}2,54 \\
6\end{array}$ & 5,161 & 8,020 & $\begin{array}{c}11,60 \\
5\end{array}$ \\
\hline 2 & B & $\begin{array}{c}2,54 \\
6\end{array}$ & $\begin{array}{c}3,17 \\
5\end{array}$ & 6,240 & 8,589 & $\begin{array}{c}11,64 \\
3\end{array}$ \\
\hline 3 & C & $\begin{array}{c}2,54 \\
6\end{array}$ & $\begin{array}{c}8,08 \\
2\end{array}$ & 4,960 & 8,020 & $\begin{array}{c}14,62 \\
0\end{array}$ \\
\hline 4 & D & $\begin{array}{c}9,73 \\
7\end{array}$ & $\begin{array}{c}8,08 \\
2\end{array}$ & $\begin{array}{c}10,14 \\
5\end{array}$ & $\begin{array}{c}11,27 \\
8\end{array}$ & $\begin{array}{c}12,22 \\
0\end{array}$ \\
\hline 5 & E & $\begin{array}{c}9,73 \\
7\end{array}$ & $\begin{array}{c}8,08 \\
2\end{array}$ & $\begin{array}{c}10,14 \\
5\end{array}$ & $\begin{array}{c}11,27 \\
8\end{array}$ & $\begin{array}{c}12,22 \\
0\end{array}$ \\
\hline
\end{tabular}

Menghitung Nilai Preferensi dari Nilai Nilai Preferensi dari Nilai dihitung sebagai berikut :

$$
\begin{aligned}
\mathrm{A}= & (2,546 * 0,2)+(2,546 * 0,3)+ \\
& (5,161 * 0,1)+(8,020 * 0,3)+ \\
& (11,605 * 0,1) \\
= & \mathbf{5 , 3 5 5 6} \\
\mathrm{B}= & (2,546 * 0,2)+(3,175 * 0,3)+ \\
& (6,240 * 0,1)+(8,589 * 0,3)+ \\
& (11,643 * 0,1) \\
= & \mathbf{5 , 8 2 6 7}
\end{aligned}
$$

$$
\begin{aligned}
\mathrm{C}= & (2,546 * 0,2)+(8,082 * 0,3)+ \\
& (4,960 * 0,1)+(8,020 * 0,3)+ \\
& (14,620 * 0,1) \\
= & \mathbf{7 , 2 9 7 8}
\end{aligned}
$$

$$
\begin{aligned}
\mathrm{D}= & (9,737 * 0,2)+(8,082 * 0,3) \\
+ & (10,145 * 0,1)+(11,278 * 0,3) \\
& +(12,220 * 0,1) \\
= & \mathbf{9 , 9 9 1 9}
\end{aligned}
$$

$$
\begin{aligned}
\mathrm{E}= & (9,737 * 0,2)+(8,082 * 0,3)+ \\
& (10,145 * 0,1)+(11,278 * 0,3)+ \\
& (12,220 * 0,1) \\
= & \mathbf{9 , 9 9 1 9}
\end{aligned}
$$

Perangkingan Berdasarkan Nilai Distance Score

Tabel 12 Menunjukkan Perangkingan Metode Oreste

\begin{tabular}{|c|c|c|c|}
\hline No & $\begin{array}{c}\text { Nama } \\
\text { Alternatif }\end{array}$ & $\begin{array}{c}\text { Nilai } \\
\text { Preference }\end{array}$ & Ranking \\
\hline 1 & A & 5,3556 & 1 \\
\hline 2 & B & 5,8267 & 2 \\
\hline 3 & C & 7,2978 & 3 \\
\hline 4 & D & 9,9919 & 4 \\
\hline 5 & E & 9,9919 & 4 \\
\hline
\end{tabular}

\section{KESIMPULAN}

Dari hasil analisa dan penerapannya, metode oreste menghasilkan alternatif $\mathrm{A}$ sebagai toko handphone terbaik di kota Padangsidimpuan dengan nilai preference $\mathrm{A}=5,3556$, dengan demikian metode Oreste mampu memecahkan masalah pemilihan toko handphone terbaik di kota Padangsidimpuan dengan menghasilkan Toko Selamat Cellular adalah toko yang terbaik atau Rangking 1

\section{DAFTAR PUSTAKA}

[1] A. Wanto and E. Kurniawan, "Seleksi Penerimaan Asisten Laboratorium Menggunakan Algoritma AHP pada AMIKSTIKOM Tunas Bangsa Pematangsiantar,'Jurnal Informatika dan Komputer (JIKO), Vol. 3, No. 1, pp. 11-18, 2018

[2] B. Febriadi, Z. Zamzami, Y. Yunefri, and A. Wanto, "Bipolar Function in Backpropagation Algorithm in Predicting Indonesia's Coal Exports by Major Destination Countries," IOP Conference Series: Materials Science and Engineering, Vol. 420, No. 12087, pp. 1-9, 2018

[3] M. Masitha, D. Hartama, and A. https://ejournal.stmikgici.ac.id/ STMIK GICI 
Wanto "Analisa Metode (AHP) pada Pembelian Sepatu Sekolah Berdasarkan Konsumen," Seminar Nasional Sains \& Teknologi Informasi (SENSASI), Vol. 1, No. 1, pp. 338-342, 2018.

[4] R. A. Hutasoit, S. Solikhun, and A. Wanto, "Analisa Pemilihan Barista dengan Menggunakan Metode TOPSIS (Studi Kasus: Mo Coffee)," KOMIK (Konferensi Nasional Teknologi Informasi dan Komputer), Vol. 2, No. 1, pp. 256-262, 2018

[5] S. Sudirman, A. P. Windarto, and A. Wanto, "Data Mining Tools RapidMiner : K-Means Method on Clustering of Rice Crops by Province as Efforts to Stabilize Food Crops in Indonesia,"IOP Conference Series: Materials Science and Engineering, Vol. 420, No. 12089, pp. 1-8, 2018

[6] E. Hartato, D. Sitorus, and A. Wanto, "Analisis Jaringan Saraf Tiruan untuk Prediksi Luas Panen Biofarmaka di Indonesia," semanTIK, Vol. 4, No. 1, pp. 49-56, 2018

[7] R. E. Pranata, S. P. Sinaga, and A. Wanto, "Estimasi Wisatawan Mancanegara yang Datang ke Sumatera Utara Menggunakan Jaringan Saraf," semanTIK, Vol. 4, No. 1, pp. 97-102, 2018

[8] F. A. Sianturi, B. Sinaga, P. M. Hasugian, T. Informatika, and S. Utara, "Fuzzy Multiple Attribute Decisison Macking Dengan Metode Oreste Untuk Menentukan Lokasi Promosi," Journal of Informatic Pelita Nusantara, Vol. 3, No. 1, pp.
63-68, 2018

[9] M. H. Wijaya, "Perancangan dan Implementasi Metode Oreste pada Sistem Pendukung Keputusan Seleksi Penerima Beasiswa," in Seminar Nasional Teknologi, 2015, pp. 387-396

[10] R. H. Sprague Jr. and H. J. Watson, "Bit by Bit: Toward Decision Support Systems," California Management Review, Vol. 22, No. 1, pp. 60-68, 1979

[11] Aldo, D. (2019). Pemilihan Bibit Lele Unggul dengan Menggunakan Metode Weighted Product. Jurnal Teknologi dan Open Source, 2(1), 15-23. 